\title{
INTElleCtuAl Property Rights ON ICT DIFFUSION IN DEVELOPING COUNTRIES
}

\author{
Ntjatji Gosebo ${ }^{1}$ and Phumudzo A. Rapea ${ }^{2}$ \\ ${ }^{1}$ Department of Public Service and Administration, South Africa \\ ${ }^{2}$ Civilian Secretariat for Police, South Africa
}

\begin{abstract}
This study seeks to determine whether information communications technologies (ICT) diffusion in developing countries is affected by intellectual property right (IPR) regimes. Literature items that were: (1) published in the last decade, (2) openly accessible, and (3) cited at least ten times, were profiled to fulfil the purpose of this study. Negative impacts of IPR regimes ranked highest among all factors used in the profiled literature of this study. The IPR factors related to the Power of Innovators were most popular among IPR factors that leaned towards the positive impacts of IPR regime. However, ICT diffusion factors were the most popular among profiled studies that tilted towards mendable impacts of IPR regimes. Consequently, this study infers that ICT diffusion in developing countries is adversely affected by IPR regimes. Limitations of this study are rooted in the fact that most studies were not freely available and access fees were prohibitively unaffordable to researchers from developing countries. This study contributes towards an understanding of IPR regimes as part of important factors that inhibit ICT diffusion in developing countries.
\end{abstract}

\section{KEYWORDS}

Intellectual Property Rights; Information Communications Technology; Developing Countries

\section{INTRODUCTION}

Globalization is an important issue of the day, and intellectual property is an important aspect of globalization, especially as the world moves toward a knowledge economy (Stiglitz, 2014). The process of economic globalization has enabled intellectual property to cross international boundaries more easily (Mohanty, 2014). Ståhle et al. (2015) examined the extent national intangible capital (NIC) explains gross domestic product (GDP) growth and to assess its impact on GDP formation in different countries, and found that intangible capital accounts for $45 \%$ of world GDP. New ideas or intellectual capital, more than savings or investments, are the new keys to prosperity and to the wealth of nations (Kefela, 2010). Consequently, in a knowledgebased economy, there is no doubt that a better understanding of IPRs is indispensable to facilitate informed policy making in all areas of human development (Suthersanen, 2006).

Intellectual property rights (IPRs) refer to those intangible assets that are legally secured through some right which entitles the owner to exclusive use of the protected matter (Hagedoorn \& Zobel, 2015; Harhoff, 2006). Therefore, it is important to point out that ownership of an idea, or ideal object, effectively gives the intellectual property (IP) owners a property right in every physical embodiment of that work or invention (Kinsella, 2001). Intellectual property rights include patents, trademarks, copyright, trade secrets and industrial designs (Kshetri, 2009). Stiglitz (2008) asserts that intellectual property, however, is different and it makes it very hard to define precisely what your property is, what somebody else's property is, and what is in the public domain. 
International Journal of Managing Public Sector Information and Communication Technologies (IJMPICT),

Vol. 6, No. 3, September 2015

In earlier stages there was non-availability of most countries' own IPR and core knowledge, thus, a country had to take sides in global competition for access to core knowledge (Choung et al., 2011). The key instrument used to achieve a shift in IPR is the World Trade Organization's Agreement (WTO) on Trade Related Aspects of Intellectual Property Rights (TRIPS), which was agreed upon in 1994, and the 1996 Copyright Agreement of the United Nations-based World Intellectual Property Organization (Lor \& Britz, 2007). The agreement represents an undertaking by members of the WTO to uphold certain minimum standards of protection for IPRs and to provide legal mechanisms for their enforcement (May, 2006). TRIPS signified the enforcement, for and on behalf of the WTO, of a new international standard, largely based on the standards of the most advanced countries (Azam, 2013).

Existing multilateral rules such as subsidies, trade policy, and IPR regimes, define limits on what is permissible (Bodansky et al., 2014). Thus, IPR regimes are governed by a mosaic of national, regional and international institutions extending from national courts and legislation, to the World Intellectual Property Organization (WIPO) in Geneva, to regional European Union (EU) rules over content (Wilson III, 2005). The WTO Agreement on Trade-Related Aspects of Intellectual Property Rights (TRIPS) calls on countries to enforce comprehensive minimum standards of IPR protection on a nondiscriminatory basis (Hoekman et al., 2005). In the case of intellectual property, one of the restrictions is that you cannot engage in abusive, anticompetitive behavior (Stiglitz, 2014).

Applicable technologies developed in richer countries may not be as readily accessible to developing countries because of intellectual property protection of privately owned technologies (Kapur \& Crowley, 2008). Therefore, there is an inevitable possibility that a violation of intellectual property law might occur, unintentionally, while providing public sector information (Turban et al., 2015). The policy choices we make now, especially in the realms of technological infrastructure and intellectual property, will have enormous implications on the future of society (Smith \& Elder, 2010). This study seeks to determine whether IPR regimes hinder or support ICT adoption by the developing countries.

The remainder of this study is presented through five sections as follows: Literature Overview, Methodology, Findings, Discussion, and Conclusions.

\section{LITERATURE OVERVIEW}

Intellectual property rights intensive goods and services constitute a rising share of the income that many developed countries derive from their presence in foreign markets (Ståhle et al., 2015; Mohanty, 2014). Consequently, the political economy of the distribution of information in the marketplace has indeed become a moral issue in the last few years, where access and use of essential information has become more difficult because of a stricter application of IPR regimes (Lor \& Britz, 2007).

Clarke (2003) observes that as the new economy is weightless and wealth creation depends upon ideas more so than on physical resources, protection of IPR regimes is paramount to Information Technology investment; thus, Governments must encourage investment in new technologies by both consumers and producers through the rigorous enforcement of intellectual property rights. Technologies such as mobile telephones and the internet allow for a greater acquisition and absorption of knowledge (McFarlane, 2009).

Intellectual property problems and proposed solutions are somewhat caused by the socioeconomic status of computer users where the income levels are far behind the position to get all necessary software programs with a license (Kuzu, 2009). Consequently, most Nigerian 
tertiary institutions solely rely on their proprietor for funding and the bulk of such fund goes to servicing the overhead cost (Achimugu et al., 2010).

The creation of local backward linkages is often seen as very beneficial for local firms, as these linkages may enhance sales and access to markets, and enables to benefit from technology transfer and training of the multinational corporations (Dunning \& Fortanier, 2006). Firms have looked increasingly to foreign markets to sell their goods and to foreign destinations as platforms for production, making it easier for intellectual property to be accessed and copied in countries that provide weak IPR protection; This is one of the major reasons why firms investing heavily in Research and Development (R\&D) are putting pressure on national governments to strengthen the international IPR regime (Anja \& Neil, 2012). If instant imitation were certain, little incentive for the costly creation of intellectual achievements would persist (Harhoff, 2006).

Intellectual property rights are indeed starting to have substantial domestic impacts in developing and developed countries which cost or save millions, depending on one's perspective (Wilson III, 2005). Poor countries and poor people differ from rich ones not only because they have less capital but because they have less knowledge and knowledge must be used to alleviate poverty and contribute to economic growth (McFarlane, 2009). All catching-up countries, including at one time the United States and Germany, have done so through a lot of imitation, reverse engineering, and straightforward copying (Cimoli et al., 2008). International regulations affect the ways in which technological knowledge can be accessed; hence, stricter IPR protection regimes severely restrict options for reverse engineering (Stamm et al., 2009). However, the concept of knowledge as private property embedded-in is new to China, given the large ignorance on IPR regimes, education and propaganda (Frietsch \& Wang, 2007).

Given the increased salience of intellectual property rights broadly and especially of patents to firms competing in the knowledge economy, it is perhaps not surprising that this increase has been accompanied by increased criticism and controversy over the functioning of patent systems throughout the world (Hall, 2007). The main debates of the past decades have concentrated on the modalities of technology transfer and intellectual property rights and thus also on the question of costs of access to technology in developing countries (Stamm et al., 2009). As the TRIPS2 agreement has increased the extent of international harmonization of IPR regimes, the question as to which elements of IPR regimes should be adopted and how they should be designed is also pertinent in many developing countries (Harhoff, 2006; Azam, 2013). If one accepts the "unfair copying" argument favouring IP protection, it follows that any subject matter which is open to imitation and copying, should be considered worthy of intellectual property protection (Suthersanen, 2006). Ownership of and access to information use a combination of technical lock-in, through the use of proprietary hardware and software, and ever more tightly defined definitions of intellectual property (often offering limited rights to use information rather than any permanent ownership of it) to secure maximum financial return on their production of information (Powell et al., 2012).

The patent systems in the United States and most other countries are often justified by an assumption that the prospect of patent protection will spur innovation, leading to the accrual of greater societal benefits than would be possible under non-patent systems (Torrance \& Tomlinson, 2009). During the 1990s, governments' promotion of high-tech sectors has been rationalized and innovated in response to the strengthening of the domestic IPR regimes (Dimaio, 2008). In the last decade, the international market for software has enjoyed the increasingly robust protection available through copyright, and as countries have become TRIPs compliant, so the ability of software companies to protect their IPRs internationally has been enhanced (May, 2006). 
Some scholars have pointed out that standard setting is actually a much politicized process, especially in the global context (Liang \& Xue, 2010). Nonetheless, the positions of the most relevant state actors in the North and South have been fairly predictable in that the United States has favoured the global extension of an intellectual property regime built around the "right to exclude" rather than the "right to distribute," while major developing economies such as China have contested this position (Boas et al., 2005). Stiglitz (2008) encapsulates intractable challenges of IPRs as follows:

"Disclosure has long been an important part of the patent and intellectual property regime. Interestingly, in some of the more recent intellectual property disputes, the notion of disclosure has been contested".

The protection of IPR regimes is of core interest for consumers in all countries, particularly in developing countries (Sell, 2010). Brazil and India take common positions at multilateral forums, especially aimed at changing trade rules to their benefit (Cervo, 2010). The concern of how IPR regimes affect the processes of economic development and growth is multidimensional and complex (Asongu1 \& Andrés, 2012). Therefore, this study seeks to determine whether IPR regimes hinder or support ICT adoption by the developing countries.

\section{RESEARCH METHODOLOGY}

To create a literature profile of the research that sheds light as to whether IPR regimes hinder or support ICT adoption by the developing countries, this study analysed scholarly articles using Google Scholar search:

(a) From 2005 to 2015,

(b) Cited at least 10 times,

(c) Freely accessible, and

(d) Google Scholar search was based on a combination of the following three phrases:

i. "ICT" - Information Communications Technology

ii. "IPR" - Intellectual Property Rights, and

iii. "Developing Countries".

The reason for using Google Scholar with open access, to fulfil objectives of this study, is because open and free access contains literature from peer-reviewed studies that are particularly freely accessible to researchers in developing countries. This study utilized general search within this literature profiling exercise, and the reason for employing a "General Search" approach is simply that it reliably facilitates the repetition of searches without any confusion; henceforth it is relatively straightforward to obtain consistent results in repetitive searches provided the same search criteria are applied (Dwivedi, 2009; William et al., 2009).

\section{Literature Profiling Results}

Google Scholar was used to find literature items that meet the selection criterion of this study, as presented in the foregoing Research Methodology section. The Google Scholar search retrieved about 6960 literature items that contained the words: "ICT", "IPR" and "Developing Countries" from 2005 to 2015 . Only 53 of the 6960 literature items were located through the Google Search with foregoing criterion were cited at least 10 times. Leanings of each of the 53 qualifying literature items emerged into three broad categories, namely, that IPRs have:

a) Positive benefits (stimulate the deployment of ICT in developing countries), 
b) Negative benefits (inhibit the deployment of ICT in developing countries), and

c) Mendable benefits (inhibit the deployments of ICT in developing countries, but, propose a way to obviate attendant negative impacts).

Table 1. Emerging Broad Categories

\begin{tabular}{|l|l|}
\hline IPR Impact & Literature items \\
\hline Positive & $33.96 \%$ \\
\hline Negative & $47.17 \%$ \\
\hline Mendable & $18.87 \%$ \\
\hline
\end{tabular}

Furthermore, each of the 53 profiled studies was analyzed to refine the above broad categories according to IPR factors that informed the respective inclinations. IPR factors that emerged from the exercise were related to the following concepts:

i. Economic Development,

ii. ICT Diffusion,

iii. Power of Innovators, and

iv. Knowledge and Innovation.

The table below recaps how each factor spreads into different impacts of IPR regimes among the 53 profiled studies. Furthermore, table 2 ranks IPR factors in accordance with frequencies of use amongst the profiled studies.

Table 2. The Spread of IPR Factors

\begin{tabular}{|l|l|l|l|l|}
\hline \multirow{2}{*}{ IPR Factor } & \multirow{2}{*}{ Frequency } & \multicolumn{3}{|c|}{ IPR Impact } \\
\cline { 3 - 5 } Innovation and Knowledge & 39 & $25.64 \%$ & $56.41 \%$ & $17.94 \%$ \\
\hline Economic Development & 32 & $21.88 \%$ & $59.37 \%$ & $18.75 \%$ \\
\hline Power of Innovators & 30 & $33.33 \%$ & $43.33 \%$ & $23.33 \%$ \\
\hline ICT Diffusion & 26 & $26.67 \%$ & $40 \%$ & $33.33 \%$ \\
\hline
\end{tabular}

Negative impacts of IPR regimes formed the highest proportion among the 53 profiled studies. It should be noted that profiled studies that lean toward Mendable IPR regime impacts also view IPR regimes as having negative impacts; but, tend to proffer likely solutions. Thus, positive impacts of IPR regimes formed the lowest proportion among the 53 profiled studies IPR factors related to Innovation and Knowledge were most popularly relied upon by 39 of the 53 profiled studies (73.58\%). ICT Diffusion related IPR factors were relied upon by 26 of the 53 profiled studies $(49.05 \%)$.

The table below summarizes IPR impact inclinations of the 53 qualifying literature items, together with factors that informed each IPR impact leaning. 
International Journal of Managing Public Sector Information and Communication Technologies (IJMPICT), Vol. 6, No. 3, September 2015

Table 3. Profiled Studies

\begin{tabular}{|c|c|c|c|c|c|}
\hline \multirow{2}{*}{$\begin{array}{l}\text { IPR } \\
\text { Impact }\end{array}$} & \multicolumn{4}{|c|}{ IPR Factors } & \multirow{2}{*}{ Author(s) } \\
\hline & Economy & ICT & Power & Innovation & \\
\hline \multirow{7}{*}{$\begin{array}{l}\frac{3}{0} \\
\frac{9}{2} \\
\frac{0}{2} \\
\frac{0}{20}\end{array}$} & & $X$ & & $\mathrm{X}$ & Benoliel \& Salama, 2010; Niosi, 2010 \\
\hline & & $\mathrm{X}$ & $\mathrm{X}$ & $\mathrm{X}$ & DiMaio, 2008 \\
\hline & & $\mathrm{X}$ & $\mathrm{X}$ & & Galperin, 2010 \\
\hline & $\mathrm{X}$ & & $\mathrm{X}$ & & An, 2009; Torrance \& Tomlinson, 2009 \\
\hline & $X$ & & $X$ & $\mathrm{X}$ & Boas et al., 2005; Hoekman et al., 2005 \\
\hline & $\mathrm{X}$ & $\mathrm{X}$ & & $\mathrm{X}$ & Spence \& Smith, 2010 \\
\hline & $\mathrm{X}$ & $\mathrm{X}$ & $\mathrm{X}$ & $\mathrm{X}$ & Odagiri \& Hiroyuki, 2010 \\
\hline \multirow{10}{*}{ 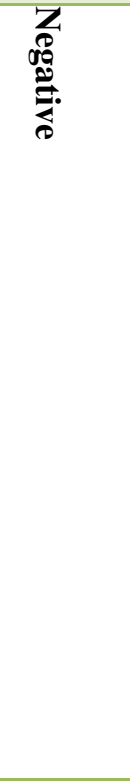 } & & & & $\mathrm{X}$ & Sun \& Du, 2010 \\
\hline & & $x$ & & $\mathrm{X}$ & $\begin{array}{l}\text { Karunasena \& Deng, 2010; Muyinda et } \\
\text { al., 2010; Smith \& Elder, } 2010\end{array}$ \\
\hline & & $\mathrm{X}$ & $\mathrm{X}$ & $\mathrm{X}$ & $\begin{array}{l}\text { Kapur \& Crowley, 2008; Larson \& } \\
\text { Murray, } 2008\end{array}$ \\
\hline & $\mathrm{X}$ & & & & Sell, 2009 \\
\hline & $X$ & & $\mathrm{X}$ & $\mathrm{X}$ & $\begin{array}{l}\text { Cimoli et al., 2008; Frietsch \& Wang, } \\
\text { 2007; Hall, 2007; Harhoff, 2006; Orsi \& } \\
\text { Coriat, 2006; } \quad \text { Stiglitz, } 2008 \text {; } \\
\text { Suthersanen, 2006 }\end{array}$ \\
\hline & $\mathrm{X}$ & & $\mathrm{X}$ & & Weber \& Bussell, 2005 \\
\hline & $\mathrm{X}$ & $\mathrm{X}$ & & $\mathrm{X}$ & Aubert, 2010 \\
\hline & $\mathrm{X}$ & $\mathrm{X}$ & & & Kattel \& Lember, 2010 \\
\hline & $x$ & $\mathrm{X}$ & & $\mathrm{X}$ & $\begin{array}{l}\text { Kefela, 2010; } \quad \text { Mansell, } 2010 ; \\
\text { McFarlane, 2009; } \\
\text { Weber, } 2011\end{array}$ \\
\hline & 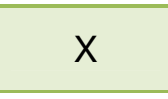 & $\mathrm{X}$ & $\mathrm{X}$ & $\mathrm{X}$ & $\begin{array}{l}\text { Lor \& Britz, 2007; May, 2006; Stamm } \\
\text { et al., } 2009\end{array}$ \\
\hline \multirow{10}{*}{ 焉. } & & & & $x$ & $\begin{array}{l}\text { As-Saber et al.2006; Callan \& } \\
\text { Cervantes, } 2005\end{array}$ \\
\hline & & & $\mathrm{X}$ & & Cervo, 2010 \\
\hline & & $\mathrm{X}$ & $\mathrm{X}$ & $\mathrm{X}$ & Lwoga, 2011; Wei et al., 2011 \\
\hline & $X$ & & & $\mathrm{X}$ & $\begin{array}{l}\text { Achimugu et al., 2010; Crawford et al., } \\
\text { 2006; Dunning \& Fortanier, } 2006\end{array}$ \\
\hline & $\mathrm{X}$ & & & & Chaminade et al., 2009; Kshetri, 2009 \\
\hline & $x$ & & $x$ & $x$ & $\begin{array}{l}\text { Arundel \& Bordoy, 2008; Choung et al., } \\
2011\end{array}$ \\
\hline & $X$ & & $\mathrm{X}$ & & $\begin{array}{l}\text { Liang \& Xue, 2010; Wiederhold et al., } \\
2009\end{array}$ \\
\hline & $\mathrm{X}$ & $\mathrm{X}$ & & & Camara \& Fonseca, 2007 \\
\hline & $\mathrm{X}$ & $\mathrm{X}$ & $\mathrm{X}$ & $\mathrm{X}$ & Asongu \& Andrés, 2012 \\
\hline & $\mathrm{X}$ & $\mathrm{X}$ & $X$ & & Wilson III, 2005 \\
\hline
\end{tabular}




\subsection{Positive Impacts of IPR Regimes}

Frequencies at which each IPR factor favored the leaning towards the positive impacts of IPR regimes (refer table 2) are ranked by dominance in the table below.

Table 4. Positive IPR Regime Impacts

\begin{tabular}{|l|l|}
\hline IPR Factor & Dominance \\
\hline Power of Innovators & $33.33 \%$ \\
\hline ICT Diffusion & $26.67 \%$ \\
\hline Innovation and Knowledge & $25.64 \%$ \\
\hline Economic Development & $21.88 \%$ \\
\hline
\end{tabular}

IPR factors related to the Power of Innovators were most popular (33.33\%) among IPR factors that leaned towards the positive impacts of IPR regimes. ICT Diffusion related IPR factors influenced a $26.67 \%$ inclination among positive impacts of IPR regimes.

\subsection{Negative Impacts of IPR Regimes}

Proportions at which IPR factors lean towards negative impacts of IPR regimes (refer table 2) are ordered according to influence in the table below.

Table 5. Negative IPR Regime Impacts

\begin{tabular}{|l|l|}
\hline IPR Factor & Dominance \\
\hline Economic Development & $59.37 \%$ \\
\hline Innovation and Knowledge & $56.41 \%$ \\
\hline Power of Innovators & $43.33 \%$ \\
\hline ICT Diffusion & $40 \%$ \\
\hline
\end{tabular}

The IPR factors related to Economic Development were the most influential (59.37\%) among IPR factors that tilt towards the negative impacts of IPR regimes. The IPR factors associated with ICT Diffusion informed a 40\% slant among IPR factors with negative impacts of IPR regimes.

\subsection{Mendable IPR Regimes}

Rates at which IPR factors contributed towards mendable IPR regimes (refer table 2) are presented in the table below.

Table 6. Mendable IPR Regime Impacts

\begin{tabular}{|l|l|}
\hline IPR Factor & Frequency \\
\hline ICT Diffusion & $33.33 \%$ \\
\hline Power of Innovators & $23.33 \%$ \\
\hline Economic Development & $18.75 \%$ \\
\hline Innovation and Knowledge & $17.94 \%$ \\
\hline
\end{tabular}

The foregoing table reveals that the IPR factors associated with ICT Diffusion had a high popularity (33.33\%) among mendable IPR regime impacts. Innovation \& Knowledge related IPR factors were least popular (17.94\%) among mendable IPR regime impacts. 
International Journal of Managing Public Sector Information and Communication Technologies (IJMPICT),

Vol. 6, No. 3, September 2015

\section{DISCUSSION OF RESULTS}

The preceding results of 53 profiled results assist to answer whether ICT diffusion in developing countries is affected by IPR regimes. The frequency at which each of the four IPR factors (see table 2) emerging from the 53 profiled studies were relied upon, ranged between $49.05 \%$ and 73.58\%. Innovation and Knowledge related IPR factors were employed by most profiled studies $73.58 \%$ to inform the impact inclinations of IPR regimes (refer table 2). The IPR factors related to ICT Diffusion were used in $49.05 \%$ of the profiled studies (refer table 2).

\subsection{Positive IPR Regime Impacts}

The 53 profiled studies supported the view that IPR regimes usher positive impacts (refer table 1) by a proportion of $33.96 \%$. Profiled studies which supported an understanding to suggest that positive impacts accrue from IPR regimes prevalently relied on $33.33 \%$ among IPR factors related to the Power of Innovators (refer table 4). The proportion of $26.67 \%$ among ICT Diffusion related IPR factors informed tendencies that the IPR regimes bring positive impacts (refer table 4).

The IPR factors related to the Power of Innovators that informed predispositions that the IPR regimes bring positive impacts relied on varied assertions. Anja \& Neil (2012) assert that IPR regimes encourage innovation by granting successful inventors temporary monopoly power over their innovations and the consequent monopoly profits provide the return on successful investment in research and development. The IPR regimes bestow owners with the power needed for innovation, whereby the significance of IPRs has increased and companies utilize IPR for strategic purposes (Stammet et al., 2009; McFarlane, 2009; Frietsch \& Wang, 2007; Andrés \& Asongu, 2012). Private companies in developed countries that are owners of technologies may be very reluctant to share specific knowledge with anchor countries, as they fear increasing competition in high-end markets from non-traditional actors that, while catching up technologically, benefit from considerably lower production costs (Stammet et al., 2009).

The ICT Diffusion factors which informed tendencies that the IPR regimes bring positive impacts, revolve around assertions that policies for the procurement of computer goods and services should ensure that options for costs and benefits are carefully evaluated (Camara \& Fonseca, 2007; Choung et al., 2011; As-Saber et al., 2006; Asongu \& Andrés, 2012).

\subsection{Negative IPR Regime Impacts}

Profiled studies that supported the view that IPR regimes convey negative impacts accounted for $47.17 \%$, which was the highest proportion among the 53 profiled studies (refer table 1). Further, negative IPR regime impacts ranked the highest in each of the four IPR factors of the 53 profiled studies (refer table 2). Economic Development related IPR factors are the most influential with a proportion of 59.37\% among IPR factors that slant towards the negative impacts of IPR regimes (refer table 5). The share of $40 \%$ among ICT Diffusion associated IPR factors informed inclinations that the IPR regimes bring negative impacts (refer table 5).

IPR regimes are not good for economic development (Anja \& Neil, 2012; Harhoff, 2006). A common finding is that the poorest countries are unlikely to benefit from strong IPR regimes (Hoekman et al., 2005; An, 2009). Anja \& Neil (2012) affirm that the early econometric research found little evidence of links between IPR protection and the volume of Foreign Direct Investment (FDI). The naive notion that more and stronger IPR regimes are always good for innovation has been refuted by scientists in empirical and theoretical work over the last decades (Harhoff, 2006). 
International Journal of Managing Public Sector Information and Communication Technologies (IJMPICT),

Vol. 6, No. 3, September 2015

The design of IPR regimes does not favour economic development in developing countries (Stamm et al., 2009; Stiglitz, 2008; Lor \& Britz, 2006; Frietsch\& Wang, 2007; Cimoli et al., 2008). Stricter IPR protection regimes severely restrict the options for reverse engineering and copycat strategies (Stammet et al., 2009). It should be clear that there is no reason to expect that the design of an IPR system, which balances costs and benefits of intellectual property protection, which is optimal for the United States, would also be optimal for developing countries (Stiglitz, 2008). However, appropriability conditions are also affected by the regimes of IPR, whereby, tighter IPR regimes imply harder conditions for imitation (Cimoli et al., 2008).

The ICT arena is characterized by the strategic control exercised by powerful corporations and nations (McFarlane, 2009; Choung et al., 2011). Computer software is generally characterized by more tenuous IPR rules (May, 2006). Though the technological character of digital goods may give the Northern countries incentives to use international institutions for bullying recalcitrant states into passing Western intellectual property laws, the same characteristics raise immense monitoring problems in the context of the international system of states; thence domestic authorities in the South are stymied by the technological difficulties of actually implementing effective digital property protection (Boas et al., 2005).

\subsection{Mendable IPR Regime Impacts}

Profiled studies that submitted for mendable IPR regime impacts (refer table 1) accounted for a total proportion of $18.87 \%$. IPR factors associated with ICT Diffusion have a high popularity (33.33\%) among mendable IPR regime impacts (refer table 6).

In essence, mendable IPR regime impact inclinations acknowledge that IPR regimes carry negative effects in developing countries, but, the situation is seen as transformable. Establishment of appropriately balanced IPR regimes and existing multilateral rules should define limits on what is permissible (Hoekman et al., 2005, An, 2009). Some countries have partly overcome these problems by creating special economic zones, techno cities and the like, that are relatively free from bureaucracy and friendly to entrepreneurs (Aubert, 2010). There is a need to determine elements of IPR regimes that should be adopted and how they should be designed in many developing countries (Harhoff, 2006; Sell, 2010; Hall, 2007). Governments' promotion of high-tech sectors should be rationalized and innovated in response to the strengthening of the domestic IPR regime (DiMaio, 2008).

The possibility of implementing different IPR rules, according to the level of economic development and the products concerned - a situation that prevailed until 1994 - was accepted because international agreements were founded on priorities of welfare and equity (Orsi \& Coriat, 2006). Beyond the regulation of IPR, several global governance institutions have begun to provide models and policy guidelines based on their own research or in collaboration with social scientists with the objective of promoting technologies in the developing world (Stamm et al., 2009); Open Educational Resources (OERs) seeks to leverage technology, skills of the in-class teacher, that utilizes not only the Internet but also lower-tech delivery platforms, and that is created not only by developed countries of the West but also by educators in many countries worldwide (Larson \& Murray, 2008); Creative Commons, a web-based organization that invites artists, photographers, musicians, educators and scholars who wish to make their work more readily available to others to post it on the Web under conditions that are less restrictive than the standard copyright conditions (Lor \& Britz, 2007). 
International Journal of Managing Public Sector Information and Communication Technologies (IJMPICT), Vol. 6, No. 3, September 2015

\section{CONClusions AND Future Research}

This study sought to determine whether ICT diffusion in developing countries is affected by IPR regimes, through a systematic literature profiling method. The inclinations of the profiled studies on the impact of IPR regimes fell into three broad categories, namely, positive (33.96\%), negative $(47.17 \%)$, and mendable $(18.87 \%)$. Consequently, $41.17 \%$ (negative) $+18.87 \%$ (mendable) $=$ $66.04 \%$ of the 53 profiled studies perceived IPR regimes as generally detrimental. The IPR factors that informed each of the three impact categories of the profiled literature emerged into a spread of four subcategories, namely, Economic Development, Innovation and Knowledge, Power of Innovators, and ICT Diffusion.

Preserving the power of innovators tended popular factors among studies that leaned towards positive IPR regime impacts, whereas innovators of IPR regimes tend to be heavily concentrated in developed countries. Studies that tilted towards the negative impacts of IPR regimes found economic development factors as the most useful tool to support their assertions; namely, that developed countries thrived without IPR regimes, and that developing countries are hindered by IPR regimes. Mendable IPR impacts are popularly based on factors related to ICT diffusion. Consequently, results of this study infer that IPR regimes tend to hinder the diffusion of ICT in developing countries.

The authors of this study could not access most literature that fitted the search conditions of this study, as access charges were required and priced in unaffordable US or European currencies. Future studies are needed to test results of this study through Chief Information Officers in developing countries.

\section{REFERENCES}

[1] Achimugu, P., Oluwagbemi, O., \& Oluwaranti, A. (2010). An evaluation of the impact of ICT diffusion in Nigeria's higher educational institutions. Journal of Information Technology Impact, $10(1), 25-34$.

[2] An, B. (2009). Intellectual property rights in information and communications technology standardization: High-profile disputes and potential for collaboration between the United States and China. Tex. Int'l LJ, 45, 175.

[3] Andrés, A. R., \& Asongu, S. A. (2013). Fighting software piracy: Which governance tools matter in Africa? Journal of business ethics, 118(3), 667-682.

[4] Anja, B., \& Neil, F. (2012). Intellectual property rights, innovation and technology transfer: a survey.

[5] Arundel, A., \& Bordoy, C. (2008). Developing internationally comparable indicators for the commercialization of publicly-funded research.

[6] As-Saber, S. N., Srivastava, A., \& Hossain, K. (2006). Information technology law and egovernment: A developing country perspective. Perspective, 1(1).

[7] Azam, M. M. (2013). Globalizing Standard of Patent Protection in WTO Law and Policy Options for the LDCS: The Context of Bangladesh. Chi.-Kent J. Intell. Prop., 13, 402.

[8] Benoliel, D., \& Salama, B. M. (2010). Towards an intellectual property bargaining theory: The post-WTO era. University of Pennsylvania Journal of International Law, 32(1).

[9] Boas, T., Dunning, T., \& Bussell, J. (2005). Will the digital revolution revolutionize development? Drawing together the debate. Studies in Comparative International Development, 40(2), 95-110.

[10] Bodansky, D., Hoedl, S. A., Metcalf, G. E., \& Stavins, R. N. (2014). Facilitating Linkage of Heterogeneous Regional, National, and Sub-National Climate Policies through a Future International Agreement. National, and Sub-National Climate Policies Through a Future International Agreement (November 1, 2014).

[11] Callan, B., \& Cervantes, M. (2005). Managing intellectual property rights from public research. Intellectual Property and Innovation in the Knowledge-Based Economy, 1.

[12] Camara, G., \& Fonseca, F. (2007). Information policies and open source software in developing countries. Journal of the American Society for Information Science and Technology, 58(1), 121132. 
[13] Cervo, A. L. (2010). Brazil's rise on the international scene: Brazil and the World. Revista Brasileira de Política Internacional, 53(SPE), 7-32.

[14] Chaminade, C., Lundvall, B. Å., Vang, J., \& Joseph, K. J. (2009). 13 Designing innovation policies for development: towards a systemic experimentation-based approach. Handbook of Innovation Systems and Developing Countries: Building domestic capabilities in a global setting, 360 .

[15] Choung, J. Y., Hameed, T., \& Ji, I. (2011). Role of formal standards in transition to the technology frontier: Korean ICT systems. Telecommunications Policy, 35(3), 269-287.

[16] Cimoli, M., Dosi, G., \& Stiglitz, J. E. (2009). Industrial policy and development: The political economy of capabilities accumulation. Oxford University Press.

[17] Clarke, M. (2003). E-development?: Development and the New Economy. UNU World Institute for Development Economics Research.

[18] Crawford, M. F., Yammal, C. C., Yang, H., \& Brezenoff, R. L. (2006). Review of World Bank Lending for Science and Technology. Science, Technology, and Innovation Discussion Paper Series, 1, 278200-1099079877269.

[19] Di Maio, M. (2009). Industrial Policies in Developing Countries. History and Prospectives.

[20] Dunning, J. H., \& Fortanier, F. (2007). Multinational enterprises and the new development paradigm: consequences for host country development. Multinational Business Review, 15(1), 2546.

[21] Dwivedi, Y.K. (2009), "Viewpoint: an analysis of e-government research published inTransforming Government: People, Process and Policy (TGPPP)", Transforming Government: People, Process and Policy, Vol. 3 No. 1, pp. 7-15

[22] Frietsch, R., \& Wang, J. (2007). Intellectual property rights and innovation activities in China: evidence from patents and publications. ISI.

[23] Galperin, H. (2010). Goodbye digital divide, Hello digital confusion? A critical embrace of the emerging ICT4D consensus. Information Technologies \& International Development, 6(SE), pp-53.

[24] Hagedoorn, J., \& Zobel, A. K. (2015). The role of contracts and intellectual property rights in open innovation. Technology Analysis \& Strategic Management, (ahead-of-print), 1-18.

[25] Hall, B. H. (2007). Patents and patent policy. Oxford Review of Economic Policy, 23(4), 568-587.

[26] Harhoff, D. (2006). Intellectual property rights in Europe-where do we stand and where should we go. Contribution to the project: Globalisation Challenges for Europe and Finland.

[27] Hoekman, B. M., Maskus, K. E., \& Saggi, K. (2005). Transfer of technology to developing countries: Unilateral and multilateral policy options. World Development, 33(10), 1587-1602.

[28] Kapur, D., \& Crowley, M. (2008). Beyond the abcs: Higher education and developing countries. Center for Global Development Working Paper, 139.

[29] Karunasena, K., \& Deng, H. (2010). Exploring the public value of e-government: An empirical study from Sri Lanka. Proceedings of Bled eConference eTrust: Implications for the Individuals. Enterprises and Society, Bled.

[30] Kefela, G. T. (2010). Knowledge-based economy and society has become a vital commodity to countries. International NGO Journal, 5(7), 160-166.

[31] Kinsella, N. S. (2001). Against intellectual property. Journal of libertarian studies, 15(2; SEAS SPR), 1-54.

[32] Kshetri, N. (2009). Institutionalization of intellectual property rights in China. European Management Journal, 27(3), 155-164.

[33] Kuzu, A. (2009). Problems Related to Computer Ethics: Origins of the Problems and Suggested Solutions. Online Submission, 8(2).

[34] Larson, R. C., \& Murray, M. E. (2008). Open Educational Resources for Blended Learning in High Schools: Overcoming Impediments in Developing Countries. Journal of Asynchronous Learning Networks, 12(1), 85-103.

[35] Liang, Z., \& Xue, L. (2010). The evolution of China's IPR system and its impact on the patenting behaviours and strategies of multinationals in China. International Journal of Technology Management, 51(2), 469-496.

[36] Lor, P. J., \& Britz, J. J. (2007). Is a knowledge society possible without freedom of access to information? Journal of information science.

[37] May, C. (2006). Escaping the TRIPs' trap: The political economy of free and open source software in Africa. Political Studies, 54(1), 123-146. 
International Journal of Managing Public Sector Information and Communication Technologies (IJMPICT), Vol. 6, No. 3, September 2015

[38] McFarlane, C. (2006) 'Knowledge, learning and development : a post-rationalist approach.', Progress in development studies., 6 (4). pp. 287-305.

[39] Mohanty, C. T. (2014). "Under western eyes" revisited: feminist solidarity through anticapitalist struggles. Signs, 40(1).

[40] Muyinda, P. B., Lubega, J. T., Lynch, K., \& van der Weide, T. (2010). Mobile learning objects deployment and utilization in developing countries. International Journal of Computing and ICT Research. Special Issue, 4, 37-46.

[41] Niosi, Jorge. "Rethinking science, technology and innovation (STI) institutions in developing countries." Innovation 12.3 (2010): 250-268.

[42] Odagiri, H., Goto, A., Sunami, A., \& Nelson, R. R. (2012). Intellectual property rights, development, and catch up: An international comparative study. Oxford University Press.

[43] Orsi, F., \& Coriat, B. (2006). The new role and status of intellectual property rights in contemporary capitalism. Competition \& Change, 10(2), 162-179.

[44] Powell, M., Davies, T., \& Taylor, K. C. (2012). ICT for or against development? An introduction to the ongoing case of Web 3.0. IKM Emergent Research Programme, European Association of Development Research and Training Institutes (EADI).

[45] Sell, S. K. (2009, September). Cat and Mouse: Forum-Shifting in the Battle over Intellectual Property Enforcement. In American Political Science Association Meeting (pp. 3-6).

[46] Smith, M., \& Elder, L. (2010). Open ICT ecosystems transforming the developing world. Information Technologies \& International Development, 6(1), pp-65.

[47] Spence, R., \& Smith, M. L. (2010). ICT, development, and poverty reduction: Five emerging stories. Information Technologies \& International Development, 6(SE), pp-11.

[48] Ståhle, P., Ståhle, S., \& Lin, C. Y. (2015). Intangibles and national economic wealth-a new perspective on how they are linked. Journal of Intellectual Capital, 16(1), 20-57.

[49] Stamm, A. (2009). Sustainability-oriented innovation systems: Towards decoupling economic growth from environmental pressures?.

[50] Stiglitz, J. E. (2008). Economic foundations of intellectual property rights. Duke Law Journal, 1693-1724.

[51] Stiglitz, J. E. (2014, December). New theoretical perspectives on the distribution of income and wealth among individuals. In International Economic Association World Congress, Dead Sea, June and forthcoming in Inequality and Growth: Patterns and Policy (Vol. 1).

[52] Sun, Y., Du, D., 2010. Determinants of industrial innovation in China: evidence from its recent economic census. Technovation 30(9-10), 540-550.

[53] Suthersanen, U. (2006). Utility models and innovation in developing countries (No. 13). International Centre for Trade and Sustainable Development (ICTSD).

[54] Tandi Lwoga, E. (2011). Knowledge management approaches in managing agricultural indigenous and exogenous knowledge in Tanzania. Journal of Documentation, 67(3), 407-430.

[55] Torrance \& Tomlinson, 2009

[56] Torrance, A. W., \& Tomlinson, B. (2009). Patents and the regress of useful arts. Colum. Sci. \& Tech. L. Rev., 10, 130.

[57] Turban, E., King, D., Lee, J. K., Liang, T. P., \& Turban, D. C. (2015). ECommerce: Regulatory, Ethical, and Social Environments. In Electronic Commerce (pp. 691-732). Springer International Publishing.

[58] Weber, S., \& Bussell, J. (2005). Will information technology reshape the North-South asymmetry of power in the global political economy?. Studies in Comparative International Development, $40(2), 62-84$.

[59] Wei, Y. D., Liefner, I., \& Miao, C. H. (2011). Network configurations and R\&D activities of the ICT industry in Suzhou municipality, China. Geoforum, 42(4), 484-495.

[60] Wiederhold, G., Tessler, S., Gupta, A., \& Smith, D. B. (2009). The valuation of technology-based intellectual property in offshoring decisions. Communications of the Association for Information Systems, 24(1), 31. William et al., 2009

[61] William, M.D., Dwivedi, Y.K., Lal, B. and Schwarz, A. (2009), "Contemporary trends and issues in IT adoption and diffusion research", Journal of Information Technology, Vol. 24 No. 1,pp. 1-10

[62] Wilson, E. J. (2005). What is Internet governance and where does it come from? Journal of Public Policy, 25(01), 29-50. 